\title{
Prognostication in Translating a Bilingual Author
}

\author{
Elena S. Petrova* \\ St. Petersburg State University \\ 7/9 Universitetskaya nab., St. Petersburg, 199034, Russia
}

Received 21.11.2014, received in revised form 19.12.2014, accepted 18.01.2015

\begin{abstract}
Probabilistic prognostication is dealt with as a cognitive process aimed by the translator at decoding the bilingual author's original communicative intent, and by the bilingual author, at anticipating and preventing potential translation flaws. Prior to the launching of the translation process, both participants pass through a situational, i.e. extralinguistic prognostication stage, where the two participants independently model the subsequent translation situation, and an optional linguistic stage, where the bilingual author anticipates potential translation problems, and the translator, potential stylistic features of the source text. During the translation process the bilingual author monitors its course and gives a critical evaluation of translation options proposed by the translator. From the standpoint of decoding the author's intent, this paper suggests, for the first time ever, distinguishing congruent, partially congruent and noncongruent prognostication. The latter, however, is not to be regarded as resulting in a translation error, if only because it is capable of providing translation gains rather than losses.
\end{abstract}

Keywords: probabilistic prognostication, translation monitoring, bilingual, congruent prognostication, noncongruent prognostication, translation gain, extralinguistic stage, situational stage, cognitive search.

Research area: philology.

\section{Introduction}

The domain of belles-lettres, or fiction translation as a subdivision of the general translation theory is increasingly coming into its own as a separate field of research in translation studies both at home and abroad. Alongside such impressionistic - or rather, popularizing works as Sublime Art by Kornei I. Chukovsky (Chukovsky, 1964) or Word Alive and Dead by Nora Gal (Gal1,975), which in their day stimulated wide public interest in the translation of prose, drama and poetry and the translator's personality, now in this area there exists a large number of research works of specialized scholarly nature. Among these the most noteworthy are the writings of T.A. Kazakova (Kazakova, 2006), in which theory sections, in keeping with university tradition, are amply illustrated with models and exercises. Fiction translation issues are also actively studied in monographs by linguists who research into, among other things, the process of searches for translation insights. This process has always been connected with foresight, which is referred

(C) Siberian Federal University. All rights reserved

* Corresponding author E-mail address: saint-petelena@mail.ru 
to by some as probabilistic prognostication, e.g. (Probabilistic Prognostication, 1977).

\section{Theoretical framework}

It is hard to overestimate the role of probabilistic prognostication in human activities. Philosophers have pointed out that former experiences and particular situations enable humans to produce hypotheses about the future and build a kind of "prelim understructure" that prepares such actions in the forthcoming situation as are the most likely to result in purpose achievement. Probabilistic prognostication in this case involves a wide range of actions, including those by the person concerned, as well as the assessment of results anticipated, the person's own time and energy expenditure. In the works by Russian translation scholars, probabilistic prognostication is primarily dealt with in connection with simultaneous and consecutive interpreting, where it has a significant effect on speech recognition, even if the latter is inhibited by various impediments.

L.L. Neliubin gives several definitions of the notion of probabilistic prognostication (veroyatnostnoe prognozirovanie), of which only two are relevant here: first, prognostication as anticipation by a person of probable developments of a situation and preparation of a response to a situation, the onset of which is deemed as the most probable, and second, probabilistic prognostication as a speech mechanism capable of predicting the appearance of some language units or others in the utterance perceived (Neliubin, 2003: 28-29). It is readily seen that that the first definition is not confined exclusively to linguistic activities or translation, whereas the second one refers directly to speech and thought acts and is therefore applicable to translation.

Adapting the first definition to translation processes and further to the subject of this research, we will infer anticipation by both the bilingual author and the translator of the possible translation situation and the specific roles of its participants. For the purposes of the present study we adopt a technical transparent term for the first definition: "situational, or extralinguistic prognostication".

Adapting the second definition to the subject of this research, we expect to speak of utterances or parts thereof perceived in one of the two languages involved in the translation situation. We therefore introduce for the second definition an equally transparent term: "intralingual prognostication".

\section{Statement of the Problem}

It is difficult to obtain material for studying the process of inter-lingual prognostication, or, for that matter, any other translation process, for the researcher usually has access to the translation result only. Obtaining experimental think-aloud protocols entails sophisticated facilities and only reflects the mental search process approximately. Therefore it seems legitimate to make use of one's own experience when the researcher is a practicing translator, resorting to the translator's reflection, verbalization and interpretation of certain stages of the mental search. In doing so, cooperation with an actively involved bilingual author enables the translator to make interesting observations regarding the cognitive processes of either party.

Bilingualism allows dual interpretation either as a mere command of the two languages or as an equal mastery of either (Neliubin, 2003: 26). In the canonical translation situation one of the participants, i.e. the translator, is bilingual by default. In the situation we are dealing with here, there are two bilingual participants - both the translator and the author. As for the author's bilingualism, since his/her novels are translated internationally (usually into the translator's native tongue - and in this particular case the writer's 
"second native" and at the same time "foreign language"), the nuances are immaterial. Since the author's command of the target language is sufficient for their participation in the translation process, the author fully qualifies to be regarded as bilingual.

Collaboration between the bilingual author and his/her translator, bilingual by definition, is an issue for cognitive studies, if only because the mental processes of these two participants may differ, converging or diverging at different points. Their collaboration is highly beneficial, indeed priceless for the translator, who then has a chance to verify his/her tentative variants and make sure whether or not their rendering is accurate, that is, reflects the author's original intent.

\section{Methods}

The above problem is best solved using the cognitive analysis method, which allows defining consecutive stages of mental search. Generally, the cognitive method is used to study mental search and the selection of translation variants (MinchenkovThis method is used to describe the translator's mental processes as well as the bilingual author's expectations with a view to his/her potential translator and the target text.

\section{Discussion}

In this section I will dwell on the processes, stages and phenomena of translation that take place in the course of translating living bilingual authors. In principle any text possesses a potential for translation. This is confirmed with particular lucidity by those cases where a work of literature receives wide public acclaim and its author begins considering chances of having it published in other languages. Even at this hypothetical stage of the translation situation, a bilingual author is in a position to undertake a kind of pre-translation adaptation of the original (which is otherwise the usual prerogative of the translator) - in other words, to turn it into a piece best suited for translation, as shown in one of my previous publications. As the American mathematician and philosopher Dr D. Hofstadter admits in writing about the pre-translation preparation of his own original text, he spent hundreds of hours paving the way for potential translations of his book into other languages. Trying to anticipate some of the difficulties to be faced by prospective translators, he went over the entire book, checking one word after another, with a red pen in his hand, and noted down every pun and acrostic, every word that could be replaced or moved if need be and all the allusions that link passages spaced wide apart in the text. He explained the secondary (tertiary, etc.) shades of meaning that were not so apparent at sight and pinpointed those passages where the form reflected the content. Furthermore, he pointed out whatever heavy wording could be lightened in translation, and specifically marked those that were expected to remain intact (Hofstadter, 2000: ix).

In other words, the author (whose command of the Russian language is such that it enables him to translate Alexander Pushkin's poetry into English) has done the following:

a) performed a situational prognostication, i.e. produced a model of his work being translated, his active role in it and collaboration with the prospective translator, as well as

b) carried out an intralingual prognostication, i.e. produced a model of the ubiquitous translation problems that could result in distortions (or remain unnoticed and overlooked) and thus affect important textuality points.

Subsequently, when the translation situation passed from a hypothetical into a real state, the bilingual author, Dr D. Hoftstadter, according to himself, actively cooperated with the translator.

In all likelihood, it is also at the preliminary stage of the translation situation that a bilingual author envisages his/her translator's profile, 
competence and experience. To optimize the translation process and collaboration with the translator, a bilingual author may ask for resumes of prospective translators of his work, as well as sample translations of his/her text, being able to appraise them. This is yet another preliminary stage that follows the virtual one and it can be referred to as a translator selection stage. The translator selection stage (which is, of course, optional) results in the ultimate choice of the second participant in the translation work and communication, i.e. the translator; thus this stage creates the necessary prerequisites for successful subsequent collaboration.

At the stage of translation proper, a bilingual author is capable of constantly monitoring the target text: looking it through, evaluating, suggesting corrections, approving particular versions and overall strategies.

The present writer's collaboration and discussions with the bilingual American novelist Olga Grushin, who wrote The Dream Life of Sukhanov (Grushin, 2007) and The Line (Grushin, 2011), has resulted in two Russian translations, Zhizn' Sukhanova v Snovideniyah (Grushina, 2011) and Ochered (Grushina, 2013), respectively, is an instance that makes it possible to observe the role of prognostication and follow-up "reconstruction" in the course of actual translation. "Reconstruction" here refers to the translator's mental decoding of the author's intent.

Collaboration with a bilingual author sets objectives of an unusual kind for the translator, who is supposed to spot purely linguistic clues permitting to decode the bilingual author's intentions. It seems pertinent to recall here the following words of one of the mid-2 $0^{\text {th }}$-century pioneers of machine translation, Dr. Warren Weaver, who said that looking at an article written in Russian, he tells himself that the text is actually written in English, but is coded with some strange symbols to be deciphered (cited from: Hofstadter, 2001: 358.).

Knowing that the author is a speaker of the target language who is well familiar with Russian culture, the translator tried to guess ("reconstruct") those Russian textual units that might have underlain the English source text as her original wording at inception stage. This process has proved especially fruitful in the case of intratextual inclusions. Thus, in one of the episodes of The Line (titled The Concert Ticket in the UK), the heroine, a Soviet teacher of literature, recalls certain poetic lines at bedtime: "She fell asleep with the words still moving through her mind $-I$ live like a cuckoo in a clock, I don't envy birds in forests, They wind me, and I sing - and their deceptively lighthearted nursery-rhyme rhythm" (Grushin, 2011: 53). If the translator does not immediately spot where the quote comes from, her translation prognostication will follow several lines. To begin with, the character is an educated person, a professional, inclined to rumination; it may therefore be surmised that the source of the above lines is a work of Russian literature.

Moreover, reference to the "deceptively lighthearted nursery-rhyme rhythm", i.e. to the piece possessing rhythm and rhyme different from the form of the cited English passage, which leads to assuming that the original is in verse. It is common knowledge that the English literary tradition, unlike the Russian one, dictates predominantly unrhymed form for sophisticated poetry in translation, whereas rhymed poetry is often regarded as characteristic of poems for children or of light poetic works. Interestingly, in this case the original text contains a word for word translation of the source poem reflecting the above English-language poetry tradition on the one hand and on the other hand it enables the translator to guess the painful lines by Anna Akhmatova that the translator can confidently pick out from her background knowledge. The 
surmise should then be confirmed by finding the exact version of the text in published sources: "Ya zhivu, kak kukushka v chasah / Ne zaviduyu ptitsam v lesakh / zavedut-i kukuyu" (Grushina, 2011:72). Thus in this case the prognostication proves to be completely congruent with the source of the intertextuality.

A similar case - except that an additional cognitive stage search for a translation solution was necessary here - is considered in example (2):

(2) ... he found the paragraph he sought and began to read... "We believe that life without Beauty is impossible, that we must attain a free and brilliant art for our descendants, one that is illuminated by the sun and induced by tireless search; we believe that we must preserve for them the Eternal values forged by many generations... Art is eternal, for it is founded on that which cannot be rejected. Art is whole, for its single source is the soul. Art is free, for it is created by the free impulse of creation..." (Grushin, 2007: 93).

The translator's background knowledge lacked any information regarding the above text. At the same time, the author's reference to the source of the intra-textual inclusion (a prerevolutionary art history magazine), coupled with its declaration-style content and stiltedly overemotional manner, prompted me a guess that I was dealing with a manifesto of some art movement. Indeed, an online search based on key words and phrases revealed that the passage was part of the foreword to the first issue of Golden Fleece magazine published in 1906. The magazine's origins were connected with some outstanding figures of Russian culture, including V. Briusov, A. Bely, A. Blok, D. Merezhkovsky and $\mathrm{K}$, Balmont. The magazine played an appreciable role in the development of Russian culture and its inclusion in the global context. As a result, the passage was translated as follows: “...mi tverdo verim, chto zhizn' bez krasoty nevozmozhna (...), nado zavoevat dlia nashikh potomkov svobodhoe, yarkoe, ozarennoe solntsem iskusstvo, vlekomoe neutolimym iskaniem, i sokhranit' dlia nikhvechnye tsennosti, vykovannye riadami pokoleniy (...) Iskusstvo - vechno, ibo osnovano na neprekhodiashchem, na tom, chto otrinut' nelzia. Iskusstvo - yedino, ibo yedinyi yego istochnik - dusha (...). Iskusstvo - svobodno, ibo sozdaetsia svobodnym tvorcheskim poryvom (...) (Grushina, 2011: 116-117).

A different kind of prognostication is revealed when the third example is considered:

(3) The works of cruel gods

In ruins lie.

Above the crumbs of columns

Swallows fly.

And men are joyful

Slavery to avoid.

Where mighty temples stood

Now lies - (Grushin, 2011:20)

Applying to the above passage the same cognitive plan of probabilistic prognostication, the translator initially assumed that it was a translated passage dating from the post-revolutionary epoch and prescribed by the school syllabus (as the reader learns from the author's description contained in the book, the schoolchildren were learning those lines by heart). Yet no such poem was found in the translator's background arsenal. Online searches for the text yielded no results either, for it had been composed by the bilingual author herself, who was well versed in the history of Russian culture. The translator therefore had to produce her own rendering of the verse in imitation of similar Russian poetry; it begins as follows: "Ruiny proshlogo / U nog lezhat. / Nad temnym kroshevom / Strizhi kruzhat / Trudu svobodnomu / Ne nuzhen hram..." (Grushina, 2013) Consequently, in cases of this kind the translator's prognostication proved only partially, not entirely, congruent with the source text - since 
predicting the authorship failed; nevertheless, the correct genre and epoch identification provided a clue for a translation approved without any objection by the bilingual author.

And finally I would like to demonstrate one more variety of prognostication that could be classified as noncongruent. It occurred in a situation where the main character hears a snatch of remarks addressed by a young girl passing by to her companion and referring to an absurdly dressed man with a bow tie askew.

The Russian translator's prognostication almost instinctively, with little cognitive effort, linked the remark with the Russian colloquial vulgar phrase "... i sboku bantik", literally 'with a bow tie (or ribbon) into the bargain', used to describe something ridiculously or amusingly absurd. The first impression was that the bilingual author, very well versed in Russian culture, had had in mind precisely that expression. Yet the author, after reading my version, wrote in an email message to the translator that the expression used in the target text was a very fitting and 'unexpected' find. It appears therefore that the prognosticated version proved to be noncongruent with the source as it was not part of the original intent to create an intertextuality effect; in the translation, however, it appeared to the bilingual author to be welcome. This gives grounds for believing that translation does not inevitably sustain losses, but may also feature gains (of discursive kind at least) that can be approved by the author. In one of the previous works (Petrova and Tonkova) my co-author and myself demonstrated how intertextuality is capable of creating additional cultural implications because of random coincidences. In those cases the translator's final decision consists in either retaining the additional cultural implication depending on the recipient of the target text or neutralizing it (e.g. by means of substitution) in order to remain loyal to the author's original intention.

\section{Conclusion}

To sum up, I have identified three varieties of probabilistic prognostication in the course of deciphering the author's intent in the sphere of intertextual inclusions. To designate these varieties, I have introduced the working terms 'congruent,' 'partially congruent' and 'noncongruent' prognostication.

Congruent prognostication completely identifies the inclusion source and the author's intent; partially congruent prognostication identifies only certain parameters of the source, and noncongruent prognostication does not reveal the inclusion source at all. It is worthy of note that partial congruity and noncongruity are not signs that the translation is successful or unsuccessful. While an individual translator is not always impartial when assessing the quality of his/her translation, its verification and appraisal by a bilingual author, provides the translator with yardsticks for including the results of cognitive searches in the ultimate version of the text translated or alternatively, for continuing the cognitive search and taking different decisions.

Applying the notions of congruent, partially congruent and noncongruent prognostication to intertextual inclusions as culturally, linguistically and cognitively significant elements of both the source and the target texts gives a further insight into translation gains rather than losses.

\section{Acknowledgement}

Privileged to have been entrusted with translating two books by the renowned novelist Olga Grushin, a perfectly bilingual speaker of English and Russian, the first and most committed reader of the target texts cited here, I extend my heartfelt thanks to Ms Grushin for her candid comments and brilliant insights into the nature of translation. 


\section{References}

1. Chernov, G.V. Foundations of Simultaneous Interpreting (Osnovy Sinhronnogo Perevoda). Vysshaya Shkola. Moscow, 1987. 256 p.

2. Chernov, G.V. Theory and Practice of Simultaneous Interpreting (Teorya i Praktika Sinhronnogo Perevoda). Vysshaya Shkola, Moscow 2007. 208 p.

3. Chukovsky, K.I. Sublime Art (Vysokoe Iskusstvo), Azbooka, St. Petersburg, 2014. P. 448.

4. Gal, N. Word Alive and Dead (Slovo Zhivoe i Mertvoe), Vremia. Moscow, 1975. P. 592.

5. Grushin, O. The Line. Penguin Books, 2011.

6. Grushin O. The Dream Life of Sukhanov. Penguin Books, 2007.

7. Grushina O. Ochered' (The Line). Translated by E. Petrova. EKSMO Moscow - Domino, St. Petersburg, 2013.

8. Grushina O. Zhizn' Sukhanova v Snovideniyakh. (The Dream Life of Sukhanov). Translated by E. Petrova. EKSMO Moscow - Domino, St. Petersburg, 2011. P. 428.

9. Hofstadter, D. Goedel, Escher, Bach: This Endless Garland (Gedel, Esher, Bah: Eta Beskonechnaya Girlianda). Bahrah-M, Samara, 2001. P. 717.

10. Kazakova T.A. Fiction Translation. Theory and Practice (Hudozhestvennyi Perevod. Teoriyai Praktika). Inyazizdat, St. Petersburg, 2006. P. 544.

11. Minchenkov, A.G. Cognitive-Euristic Translation Model: Theoretical Framework,Verification, Possible Applications (Kognitivno-Evristicheskaya Model Perevoda:Teoreticheskie Osnovy,Verifikatsiua, Vozmozhnosti Prilozheniya). LAP Lambert Academic Publishing, Saarbrücken, 2011. $278 \mathrm{p}$.

12. Neliubin, L.L. Explanatory Dictionary of Translation Studies (Tolkovyi Perevodovedcheskii Slovar). Flinta-Nauka, Moscow, 2003. P. 318.

13. Petrova, E.S.,and Tonkova,N.I. Title Intertextuality in the Linguistic-Cultural Space of the Source and Target Text (Intertekstualnost Zaglaviy v Lingvokulturnom Prostranstve Podlinnika $i$ Perevoda). Universitetskoe Perevodovedenie. Vol. 5. SPbGU, St.Petersburg, 2004. P. 261-270.

14. Probabilistic Prognostication in Human Activity (Veroyatnostnoe Prognozirovanie $v$ deyatelnosti cheloveka / Eds. I.M. Feigenberg and E.G. Zhuravleva, Nauka, Moscow, 1977. P. 389. 


\title{
Вероятностное прогнозирование \\ в процессе перевода произведений автора-билингва
}

\section{Е.C. Петрова}

Санкт-Петербургский государственный университет Россия, 199034, Санкт-Петербург, Университетская наб., 11

\begin{abstract}
Вероятностное прогнозирование рассматривается как когнитивный процесс, ориентированный, с позиций переводчика, на вскрытие первоначального коммуникативного намерения автора-билингва, а с позиций автора-билингва - на предотвращчение потенциильных погрешностей перевода. До начала процесса перевода прогнозирование проходит экстралингвистическую стадию, где партиципанты независимо друг от друга моделируют ситуацию последующего перевода, а также факультативную собственно лингвистическую стадию, на которой автор прогнозирует проблемные фрагменть своего исходного текста, а переводчик - специфику языка и стиля автора. Автор-билингв проводит мониторинг процесса перевода и критически оченивает решения, принятье профессиональным переводчиком. С точки зрения декодирования авторского намерения, впервые предложено различать конгруэнтное, частично конгруэнтное и неконгруэнтное вероятностное прогнозирование переводчика. Подчеркивается, что неконгруэнтное прогнозирование не приравнивается $к$ переводческой ошибке, поскольку оно способно обеспечить переводческую находку, а не потерю.
\end{abstract}

Ключевые слова: вероятностное прогнозирование, мониторинг перевода, билингв, конгруэнтное прогнозирование, неконгруэнтное прогнозирование, переводческое приобретение, экстралингвистическая стадия, ситуативная стадия, когнитивный поиск.

Научная специиальость: 10.00.00 - филологические науки. 